\title{
Progress Report for the Project: Comparison of the Response of Mature Branches and Seedlings of Pinus ponderosa to Atmospheric Pollution
}

\author{
James L. J. Houpis \\ Paul D. Anderson \\ Sharon E. Benes \\ Steven P. Phelps \\ A. Thorpe Loeffler
}

Ecosystem and Measurement Sciences Section

Environmental Sciences Division

Lawrence Livermore National Laboratory

P.O. Box 5507, L-524

Livermore, California 94550

July 2, 1990 


\section{TABLE OF CONTENTS}

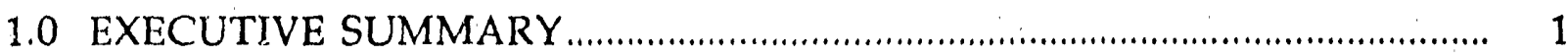

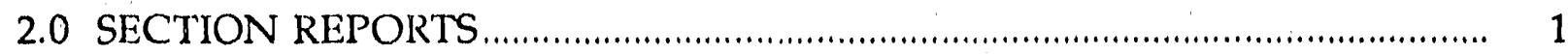

2.1 Treatment Application ....................................................................... 1

2.1.1 Ozone Fumigation................................................................... 1

2.1.2 Acid Precipitation ......................................................................... 2

2.2 Branch Exposure Chamber-Design Changes .......................................... 4

2.3 Data Acquisition and Monitoring .......................................................... 5

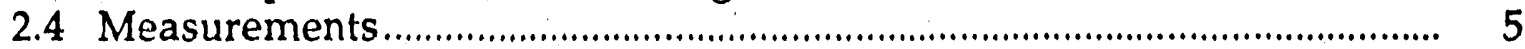

2.4.1 Seedling and Branch Morphology .............................................. 5

2.4.2 Water Relations ............................................................................... 5

2.4.2.1 Pre-dawn Foliar Water Potential.............................................. 5

2.4.2.2 Neutron-Probe Soil Moisture Measurements...................... 6

2.4.3 Physiological Measurements........................................................ 8

2.4.3.1 Gas-Exchange Measurements................................................ 8

2.4.3.2 Foliar Nutrient Analyses ....................................................

2.4.3.3 Pigmentation ............................................................... 10

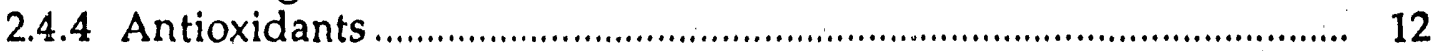

2.4.4.1 Methods Development.................................................... 12

2.4.4.2 Within-Branch Variability Sampling and Assays................ 13

2.4.4.3 Diurnal Variability Sampling and Assays ............................ 13

2.4.4.4 Seasonal Variability Sampling and Assays ......................... 13

2.4.4.5 Episode Variability Sampling and Assays ........................... 13

2.4.4.6 Interpretation of Preliminary Data ..................................... 14

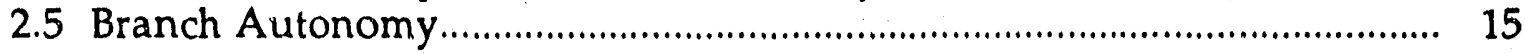

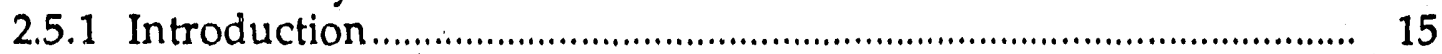

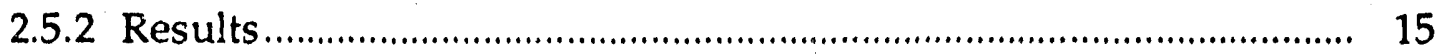

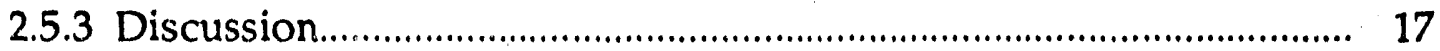

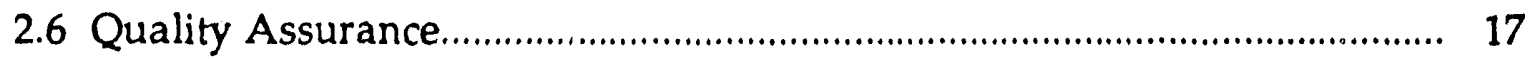

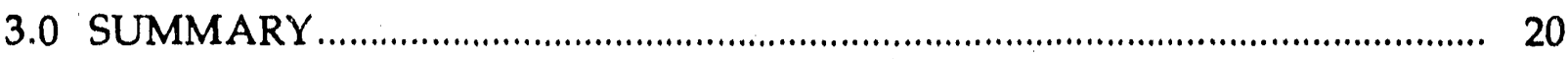

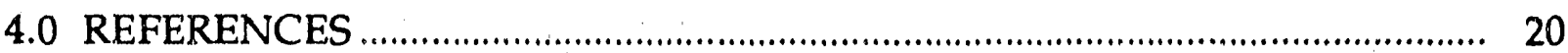

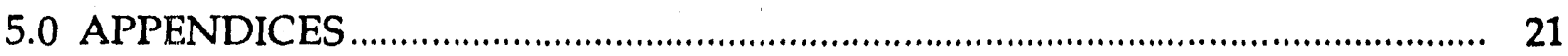

Appendix A: External Project Reporting ..................................................... 21

Appendix B: Standard Operating Procedure for Antioxidant Analyses ........ 23 


\subsection{EXECUTIVE SUMMARY}

This progress report details Lawrence Livermore National Laboratory's (LLNL) performance regarding the projects "Comparison of the Response of Mature Branches and Seedlings of Pinus ponderosa to Atmospheric Pollution" and "Effects of Ozone, Acid Precipitation, and Their Interactions on Mature Branches and Seedlings of Ponderosa Pine" (Western Conifer Research Cooperative Project Number: WC20) for the months of November 1989 to June 1990.

During the last eight months, we have initiated ozone and acid precipitation exposures, and we began intensive growth, morphological, and physiological measurements. Measurements have followed the schedule outlined in Houpis et al. (1987), with major physiological measurements occurring in November (preexposure measurements) and March (before stem and needle elongation). During these major physiological measurement periods, we measured photosynthesis, transpiration, stomatal conductance, respiration, antioxidant activity, pigmentation, and foliar nutrient concentration. As expected, we did not observe any ozoneinduced physiological effects because of the low concentrations of ozone during the winter months.

We have also concluded the analysis of our branch autonomy experiment, which we conducted in the fall. We determined that virtually no carbon is exported among branches in close proximity to one another. This conclusion assists in validating the approach of using branches and branch exposure chambers as a means of assessing the effects of air pollution on mature trees of Ponderosa pine.

Over the last eight months, numerous mechanical and electrical problems arose that hampered the smooth functioning of the research facility at Chico, CA. These types of problems are expected to occur in establishing a large exposure facility. However, the magnitude and frequency of these operational problems have decreased to minimal levels, so the facility functions smoothly and interruption of exposures rarely occurs.

Since January 1990, we have published three abstracts in Plant Physiology, published one paper in the Proceedings from the North American Forest Biology Workshop, submitted two manuscripts to journals (Tree Physiology and Journal of Environmental Quality), and given three presentations. References to the above papers are given in Appendix A, and copies have been sent under a separate cover.

\subsection{SECTION REPORTS}

\subsection{Treatment Application}

\subsubsection{Ozone Fumigation}

During the first month of fumigation, much effort was spent calibrating the distribution of ozone-enhanced air streams to the chambers. Initially, many difficulties arose in the performance of this task. The principal difficulty arose from 
varying efficiency in the generation of ozone from our ozone generator (PCI, Inc., West Caldwell, NJ). The amount of ozone generated is controlled by monitoring the ambient ozone concentration and adjusting the spark generator voltage inside the ozone generator. The spark generator voltage, in turn, is adjusted by using a motorized potentiometer driven by the data acquisition system (DAS). The problem encountered is that the percent conversion of ambient oxygen to ozone as a function of potentiometer voltage is subject to change with varying environmental conditions. Discussions with the manufacturer of the generator suggested that the problem arose because ozone-conversion efficiency was dependent on the watervapor concentration and the temperature of the air stream entering the ozone generator. Humidity of the air stream varied as a result of changes in relative humidity of the ambient air and also from condensation formed by the air compressor used to drive the system.

To mitigate the water-vapor problem, we have focused on drying the pressurized air stream used for ozone generation. This has been accomplished in two phases. We installed a water trap, oil trap, and series of desiccating columns (calcium sulfate desiccant) in the air-supply line downstream from the air compressor and upstieam from the ozone generator. Although this reduced the fluctuation in water-vapor concentration, the problem was not completely resolved because the desiccant was rapidly spent (replacement of the desiccant was required on a daily basis). To further reduce the water-vapor concentration, a differentially permeable drying column (Perma-pure Products, Inc., Tom's River, NJ) was installed between the water trap and the desiccant columns. The air supply for the ozone generator flows through the drying column, which is permeable to water vapor, and the drying column is surrounded by a purge space, which is evacuated at a high flow rate. Because of the vapor-pressure gradient between the air in the drying column and the air in the purge space, a large percentage of the water vapor in the air supply for the ozone generator flows to the purge space and is exhausted from the system.

\subsubsection{Acid Precipitation}

Installation of the acid-precipitation system occurred in several phases. First, pump assemblies were mounted at the specified tree platforms and on the seedling branch exposure chamber (BEC) support structures. Second, following several iterations in system development, we installed the tubing for solution delivery. Third, adjustments and calibration of solution delivery were carried out using tap water. Fourth, solution-catchment systems for both the seedling BECs and the mature branch BECs were designed and constructed. Fifth, we conducted acid-rain test-run events using deionized water. Finally, we began the actual acid-rain treatment events.

The system design we implemented is very similar to the design described in the original proposal. All the BECs on a given tree receive the same acid-rain treatment level. One pump draws solution from a single carboy and delivers it to all three BECs by means of a three-way distribution manifold. The delivery pressure for all three nozzles is baianced at $10 \mathrm{psi}$ using three pinch clamps positioned 
downstream from the manifold. In addition, the volumetric flow rate of the pump exceeds the rate required to achieve the specified nozzle discharge rate. This excess flow from the pump is returned to the solution carboy through a low-volume return line that is plumbed into the main delivery line upstream from the manifold. The flow rate through the return line is also controlled using a pinch clamp. The delivery system for the seedling BECs is similar to that used for the mature branch BECs (including one pump per three BECs) except that treatment levels are randomly allocated to each seedling BEC.

Measurements of the nozzle volumetric flow rate indicate that at the specified pressure of $10 \mathrm{psi}$, a higher mean flow rate $\left(36.4 \mathrm{l} \cdot \mathrm{hr}^{-1}\right)$ occurs in the field compared to that observed in tests performed at LLNL $\left(26.81 \cdot \mathrm{hr}^{-1}\right)$. This difference is probably the result of our current use of tygon tubing for the main delivery line rather than the more rigid teflon tubing we used in the laboratory. As a result of the higher volume flow rate, the mean rainfall intensity in the BEC is $5.8 \mathrm{~cm}^{\circ} \mathrm{hr}^{-1}$ rather than $4.3 \mathrm{~cm} \bullet \mathrm{hr}^{-1}$ as indicated in laboratory testing.

The acid-precipitation catciment systems for the BECs are designed to prevent acid solution from entering the soil in the vicinity of the trees and seedlings. The branch-BEC catchment system consists of a funnel-shaped plastic collar attached to the branch below the BEC. This collar is gathered around the branch at the base of the exposed tissue so a water-tight seal is formed. Extra collar material is also gathered to form a channel that drains the collar into plastic ducting $(25.4 \mathrm{~cm}$ in diameter) that is suspended from the bottom of the BEC. The plastic ducting for all three BECs per tree extends down to a $125-1$ plastic container resting on the ground. Solution from the BEC drains through the collar, down the ducting, and into the plastic container.

The catchment system or the seedlings consists of a circular sheet of plastic placed around the base of the BEC, which is sealed with vinyl tape around the stems of the four seedlings. Approximately 75 percent of the perimeter of the plastic sheet is attached to the frame of the BEC. The other 25 percent of the plastic sheet is placed in a $75-\mathrm{cm}$ segment of plastic rain gutter, which is embedded in the soil. The rain gutter drains the acid-precipitation solution into a 20-1 plastic jug. The plastic ground sheet must be installed for each rain event. If left in place between rain events, the plastic sheet would retard normal soil aeration and would also cause elevation of the soil surface temperature.

As a result of delays in the winter involving the perfection of the ozone generation system mentioned in Section 2.1.1, application of the acid-rain treatments was postponed. A new application schedule has been adopted that places priority on the application of a total rain volume equal to that observed during one rain season in the central Sierra Nevada. A total of $132 \mathrm{~cm}$ of rain will be applied. Rain events will occur twice per week and will conclude at the end of August 1990. The deposition for each event will be $4 \mathrm{~cm}$. To minimize potential adverse effects of heat damage to the foliage, acid-rain treatments will be applied at times of low light intensity in the early morning. 


\subsection{Branch Exposure Chamber-Design Changes}

A $B E C$ raising mechanism (BRM) must satisfy certain requirements. Above all, we must be able to raise and lower the $\mathrm{BEC}$ without damaging the branch. The $B R M$ must not present a danger to the branch itself, and the BRM also needs to be convenient to use. We need to be able to raise and lower the chamber and easily set its height, and we should be able to do this from deck level.

The original BRM had some problems that have been rectified. Originally, we set the BECs by means of a single guy wire and bungee cords. The guy wire is made of stainless steel cable and runs through two eye bolts attached to the back of the chamber. The bungee cords served a dual purpose: they prevented the chamber from swinging in the wind, and they also held the chamber up. The guy wire worked well, and it has been retained. The bungee cords prevented the BECs from swinging in the wind, but failed as a means of holding the BEC up. The problem was that as the bungee cords stretched with age, permanent anchor points for them became nearly impossible to find. This problem would also be compounded as the branch grows.

There was another problem with the original BRM. A long cable was strung behind the guy wire, and both were extended from the ground to the top of the BEC support. That second cable ran through two pulleys: one at the top, mounted to the $B E C$ support, and one on the ground. The second cable, which was attached to the chamber, could be used to raise and lower the chamber, but only while the investigator was standing on ground level. The original system did not allow us to raise the chamber while standing on the deck of the platform. Furthermore, on some platforms the secorid cable had a tendency to jam in the upper pulley, and it also tended to rub on tree branches.

The original BRM was discarded in favor of a better design. The new BRM uses a single pulley mounted directly over the BEC and, instead of steel cable and bungee cords, employs nylon line. This line, unlike the previously used cable, actually supports the weight of the BEC and, therefore, will be referred to as the "support line." This support line is attached to the BEC by a three-way bridle made with more nylon line. The support line ties into the three bridle lines by a triple sheet turn knot, which is deliberately tied off center so the line clears the ducting that attaches to the top of the BEC. The other end of the support line ties off to one of the BEC support side posts by means of a dual horn cleat; thus, it supports the weight of the BEC. The cleat allows easy removal of the line and adjustment of the height of the BEC.

The new system offers several advantages over the original. The design of the support line, in conjunction with the cleat, allows infinite adjustability of BEC. height. This will become more necessary as the tree branches grow. Furthermore, the BEC is now held up in a more positive fashion and a healthy degree of redundancy has been added. If the support line breaks, the bungee cords (which have been left in place to reduce wind-induced swing of the BEC) will reduce damage from occurring to the branch. Also, it is easier to raise and lower the BECs.

The nylon line will weather with time, which may or may not be a problsm, depending on how long the project lasts. There is enough redundancy in the 
present design so that even if a bridle line or even a support line breaks, the BEC will stay up, thus minimizing any possible damage to branches. The system is designed for easy repair, in the event any repair is needed, and the line is inexpensive as well.

\subsection{Data Acquisition and Monitoring}

We have been acquiring environmental data since September 1989. A recurring problem with the atmospheric sampling has occurred due to failure of the 12-position sample valves (Scartivalve, Inc., San Diego, C.A). The valves have frequently stuck, thus preventing the position advancement necessary for sampling all 12 ports. In some instances, this has resulted in the loss of data as well as further mechanical damage to the valve. Upon investigation, it has been determined that the sticking has occurred because of the formation of condensation and the accumulation of fine dust within the stator-rotor assembly of the valve.

The problem has decreased in severity since May 1990. Warmer temperatures at night have resulted in less condensation in the sample lines. Also, a teflon lubricating oil has been added to the stator-rotor assembly. However, to date, 11 of the 13 valves in the system have required repair. Three valves have been sent to the manufacturer to have the stator-rotor surfaces remachined; this is an expensive, lengthy solution. Unfortunately, more valves may require work in the future.

\subsection{Measurements}

\subsubsection{Seedling and Branch Morphology}

Baseline morphological and growth measurements were taken throughout 1989. Morphological and growth measurements during exposures were begun in mid-March 1990. Needle elongation and shoot length are measured at two-week intervals. Seedling stem caliper and branch caliper are measured monthly. Measurements are made on all experimental branches, all BEC seedlings, and five seedlings per open-top chamber (OTC). The seedlings planted into BECs in February 1990 are measured on alternate weeks from the seedlings planted in 1989.

\subsubsection{Water Relations}

\subsubsection{Pre-Dawn Foliar Water Potential}

Measurements of pre-dawn foliar water potential have been conducted on the mature branches at two-week intervals since mid-April. Due to the relatively small amount of foliage, foliar water-potential measurements have not been made for the seedlings. Removal of fascicles from the seedlings could not be made without potentially altering their physiological performance. Measurements for seedlings may occur after their 1990 foliage has more fully developed. 


\subsubsection{Neutron-Probe Soil Moisture Measurements}

Due to variability in the application of irrigation water, study trees in the orchard may experience different soil-moisture conditions. A neutron probe is being used to measure available soil water near six experimental trees. These trees, numbered 1,4,6,8,16, and 17 (Fig. 1) were selected because they receive ozone as the only treatment.

Aluminum neutron-probe access tubes were installed $3 \mathrm{~m}$ north of each tree trunk. The tubes extend to a soil depth of $125 \mathrm{~cm}$ and have a $45-\mathrm{cm}$ segment extending above the soil surface. Measurements, recorded as counts, are made at $25-\mathrm{cm}$ depth increments to a depth of $125 \mathrm{~cm}$. The measurement time period is $16 \mathrm{~s}$. Counts are converted to a count ratio by standardization against the counts measured with the neutron source housed in the shielded instrument casing.

One objective in making neutron-probe measurements is to provide data for examining the relationships between foliar water potential and soil moisture status. Needle water potential, as measured with the pressure chamber, is expressed as bars, a unit of pressure. For purposes of comparison, it is desirable to express soil water content in the same units.

To convert a count ratio from the neutron probe to bars, a calibration relationship specific to the soil type present in the orchard must be derived. Development of the calibration relationship consists of two components. First, the relationship between volume of water present in the soil and neutron-probe count ratio must be defined. Second, the relationship between volumetric water content and soil water potential must be determined.

The relationship between volumetric water content and neutron-probe count ratio will be derived in the course of orchard irrigation. Neutron-probe counts will be made immediately before and $24 \mathrm{~h}$ following the application of irrigation water. These measurements will be integrated over the soil profile to provide a ratio between the volume of water added per unit soil volume and the change in neutron-probe count ratio.

The relationship between soil volumetric water content and soil water potential will be determined using a pressure membrane apparatus. Four intact soil cores of known volume will be removed from a depth of $50 \mathrm{~cm}$ near each access tube. The samples will be transported in metal containers to the Soil Science Laboratory at California State University, Chico. During the month of September, the soil cores will be stepped through a series of progressively increasing pressures on the membrane device. As equilibrium is achieved at each step, the volumetric water content of each core will be determined by weighing the known volume of soil. The resulting data will be used to generate a soil moisture release curve relating equilibrium pressure to volumetric water content.

Estimates of soil water potential will be derived by relating a neutron-probe count ratio to soil volumetric water content. In turn, soil water potential will be estimated from the volumetric water content and the derived soil moisture release curve. Ultimately, the relationship between foliar water potential and soil water potential will be examined using correlation analyses. 


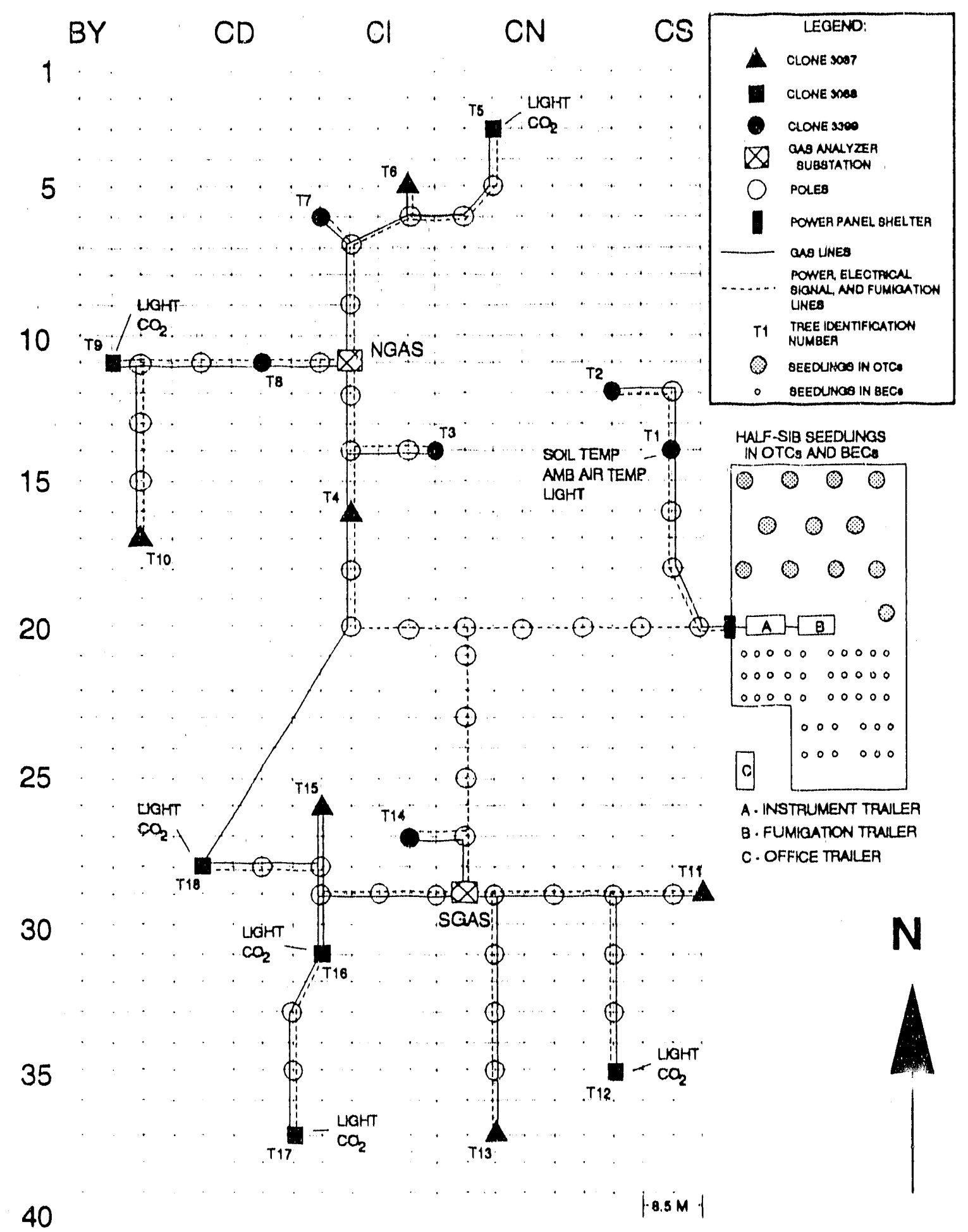

Figure 1. Chico Air Pollution and Climate Change Research Facility. 


\subsubsection{Physiological Measurements}

\subsubsection{Gas-Exchange Measurements}

The second set of intensive physiological measurements were made in March 1990. The onset of warm weather and phenological change in the plant tissues occurred earlier than anticipated. Bud elongation began in early March for both seedlings and branches. Observations suggest that tissue in the chambers began growth activity at least one week prior to the initiation of growth by nonchambered tissue.

The measurements occurred over three days, March 26-28, 1990. The gasexchange characteristics of mature branches and seedlings of clone 3088 exposed in BECs were measured on March 26th. On March 27th, pre-dawn and diurnal measures of foliage water potential of the mature branch tissue of clones 3087,3088 , and 3399 were made in conjunction with gas-exchange measurements. The diurnal gas-exchange characteristics of clone 3088 seedlings grown in open-top chambers and BECs were measured on March 28th.

Gas-exchange data for November 1989 have been entered and completely reduced. The November data have undergone preliminary analyses, and the gasexchange data for March have been entered onto magnetic disk.

\subsubsection{Foliar Nutrient Analyses}

The laboratory analyses of mature-branch foliar-nutrient concentrations have been performed for both November 1989 and March 1990 sampling periods (Table 1). The observed values for all elemerits are within observed ranges for naturally occurring Pinus ponderosa. The concentrations of $\mathrm{Mn}$ are moderately low, and the concentrations of $\mathrm{P}, \mathrm{Na}$, and $\mathrm{Fe}$ are slightly low compared to those in natural stands. Concentrations of $\mathrm{Ca}, \mathrm{Mg}, \mathrm{K}$, and $\mathrm{S}$ are relatively high.

Preliminary analysis of variance (ANOVA) indicates that ozone did not affect any of the nutrient parameter's (Table 2). However, the foliar concentrations for several elements differed significantly between measurement dates. The foliar concentrations of $\mathrm{Ca}, \mathrm{Zn}$, and $\mathrm{B}$ were greater in March than in November. The foliar concentrations of $\mathrm{N}$ and $\mathrm{P}$ were lower in March. The accumulation of $\mathrm{Ca}$ is expected because of it; incorporation into cell wall material. The decreases in $\mathrm{N}$ and $P$ may be due to either remobilization or to dilution associated with carbon accumulation. This issue will be evaluated in subsequent analyses of nutrient concentrations based on foliar surface area rather than tissue dry weight.

Foliar concentration differences arnong clones were observed for all elements other than $\mathrm{Na}$ and $\mathrm{S}$. Clone 3088 had the lowest concentrations for all elements other than S. Clone 3399 had the highest concentrations for all elements other than $\mathrm{N}$ and $\mathrm{Mg}$. For those elements, there was little difference in concentration between clones 3087 and 3399. Most interestingly, there appears to be a strong positive correlation between phenotypic vigor of the three clones and their relative foliar concentrations of $\mathrm{P}, \mathrm{Mg}, \mathrm{Ca}, \mathrm{Zn}$ and $\mathrm{B}$. Rarnets of clone 3399 have the best visual expression of vigor and also have the highest mean foliar concentrations 
Table 1. Foliar nutrient concentrations for mature branches. Means and standard deviations (s.d.) are presented for all samples and for each clone for the November 1989 and March 1990 sampling dates.

\begin{tabular}{|c|c|c|c|c|c|c|}
\hline \multirow[b]{2}{*}{ Element } & \multirow[b]{2}{*}{ Source } & \multirow[b]{2}{*}{$\mathrm{n}$} & \multicolumn{2}{|c|}{ November } & \multicolumn{2}{|c|}{ March } \\
\hline & & & mean (ppm) & s.d. $\%$ & mean (ppm) & s.d. $\%$ \\
\hline \multirow[t]{4}{*}{ Nitrogen } & overall & 72 & 1.33 & 0.092 & 1.19 & 0.084 \\
\hline & 3087 & 24 & 1.35 & 0.096 & 1.21 & 0.083 \\
\hline & 3088 & 24 & 1.29 & 0.089 & 1.14 & 0.060 \\
\hline & 3399 & 24 & 1.34 & 0.084 & 1.22 & 0.088 \\
\hline \multirow[t]{4}{*}{ Calcium } & overall & 72 & 0.239 & 0.044 & 0.259 & 0.051 \\
\hline & 3087 & 24 & 0.225 & 0.049 & 0.247 & 0.044 \\
\hline & 3008 & 24 & 0.233 & 0.038 & 0.231 & 0.037 \\
\hline & 3399 & 24 & 0.261 & 0.039 & 0.301 & 0.043 \\
\hline \multirow[t]{4}{*}{ Magnesium } & overall & 72 & 0.188 & 0.033 & 0.185 & 0.029 \\
\hline & 3087 & 24 & 0.195 & 0.038 & 0.185 & 0.028 \\
\hline & 3088 & 24 & 0.170 & 0.018 & 0.168 & 0.016 \\
\hline & 3399 & 24 & 0.201 & 0.034 & 0.203 & 0.032 \\
\hline \multirow[t]{4}{*}{ Potassium } & overall & 72 & 0.891 & 0.153 & 0.858 & 0.147 \\
\hline & 3087 & 24 & 0.825 & 0.143 & 0.765 & 0.093 \\
\hline & 3088 & 24 & 0.848 & 0.156 & 0.842 & 0.154 \\
\hline & 3399 & 24 & 1.005 & 0.088 & 0.966 & 0.115 \\
\hline \multirow[t]{4}{*}{ Sodium } & overall & 72 & 0.00241 & 0.00101 & 0.00233 & 0.00073 \\
\hline & 3087 & 24 & 0.00229 & 0.00069 & 0.00233 & 0.00076 \\
\hline & 3088 & 24 & 0.00254 & 0.00114 & 0.00233 & 0.00082 \\
\hline & 3399 & 24 & 0.00239 & 0.00116 & 0.00233 & 0.00064 \\
\hline \multirow[t]{4}{*}{ P'hosphorus } & overall & 72 & 1483 & 212.1 & 1310 & 212.5 \\
\hline & 3087 & 24 & 1484 & 150.6 & 1278 & 135.1 \\
\hline & 3088 & 24 & 1277 & 93.8 & 1110 & 100.3 \\
\hline & 3399 & 24 & 1698 & 123.3 & 1541 & 111.4 \\
\hline \multirow[t]{4}{*}{ Sulfur } & overall & 72 & 1107 & 131.9 & 1098 & 139.5 \\
\hline & 3087 & 24 & 1059 & 103.5 & 1030 & 94.7 \\
\hline & 3088 & 24 & 1129 & 140.8 & 1123 & 177.3 \\
\hline & 3399 & 24 & 1134 & 140.0 & 1143 & 109.6 \\
\hline \multirow[t]{4}{*}{ Manganese } & overall & 72 & 66.1 & 17.6 & 62.3 & 15.4 \\
\hline & 3087 & 24 & 71.9 & 21.4 & 66.0 & 18.4 \\
\hline & 3088 & 24 & 60.2 & 15.0 & 55.2 & 12.2 \\
\hline & 3399 & 24 & 66.2 & 14.0 & 65.7 & 13.0 \\
\hline \multirow[t]{4}{*}{ Aluminum } & overall & 72 & 49.9 & 15.4 & 53.1 & 15.5 \\
\hline & 3087 & 24 & 45.8 & 10.2 & 49.3 & 10.1 \\
\hline & 3088 & 24 & 54.2 & 19.0 & 53.1 & 19.5 \\
\hline & 3399 & 24 & 49.8 & 15.1 & 57.0 & 14.8 \\
\hline
\end{tabular}


Table 1. Continued.

\begin{tabular}{|c|c|c|c|c|c|c|}
\hline \multirow[b]{2}{*}{ Element } & \multirow[b]{2}{*}{ Source } & \multirow[b]{2}{*}{$n$} & \multicolumn{2}{|c|}{ November } & \multicolumn{2}{|c|}{ March } \\
\hline & & & mean (ppm) & s.d. \% & mean (ppmi) & s.d. $\%$ \\
\hline \multirow{4}{*}{ Iron } & overall & 72 & 61.8 & 12.4 & 60.4 & 13.0 \\
\hline & 3087 & 24 & 59.6 & 9.6 & 58.2 & 9.8 \\
\hline & 3088 & 24 & 62.3 & 14.3 & 57.9 & 17.3 \\
\hline & 3399 & 24 & 63.5 & 13.2 & 65.1 & 9.7 \\
\hline \multirow[t]{4}{*}{ Zinc } & overall & 72 & 28.7 & 9.2 & 33.1 & 12.1 \\
\hline & 3087 & 24 & 26.8 & 7.8 & 29.8 & 11.5 \\
\hline & 3088 & 24 & 22.8 & 3.9 & 28.2 & 10.1 \\
\hline & 3399 & 24 & 36.8 & 9.0 & 41.2 & 10.7 \\
\hline \multirow[t]{4}{*}{ Boron } & overall & 72 & 35.3 & 5.27 & 40.9 & 7.16 \\
\hline & 3087 & 24 & 36.6 & 4.61 & 42.3 & 6.68 \\
\hline & 3088 & 24 & 31.8 & 4.90 & 37.6 & 6.18 \\
\hline & 3399 & 24 & 37.7 & 4.45 & 42.8 & 7.63 \\
\hline \multirow[t]{4}{*}{ Copper } & overall & 72 & 3.20 & 0.688 & 3.28 & 0.602 \\
\hline & 3087 & 24 & 3.03 & 0.643 & 3.13 & 0.682 \\
\hline & 3088 & 24 & 3.01 & 0.571 & 3.35 & 0.480 \\
\hline & 3399 & 24 & 3.52 & 0.756 & 3.35 & 0.628 \\
\hline
\end{tabular}

of those elements. In contrast, ramets of clone 3088 have the worst appearance and also have the lowest concentrations of the above-mentioned elements.

\subsubsection{Pigmentation}

Measurements of the foliar concentrations of chlorophyll A, chlorophyll B, and carotenoids were made for samples collected in November 1989 and March 1990. Because of the limited amount of seedling foliage present, analyses were made on mature branch foliage only. These data were subjected to ANO' $A$ to determine the effect of sample date, clone, and ozone. Acid rain was not included as a factor in the analyses because treatments had not been initiated at the time of sampling. Results from the ANOVA are presented in Table 3.

Application of Tukey's multiple comparison test revealed the following information regarding differences among the factor level means:

A. The concentration of chlorophyll A was greater in needles from clone 3399 than in needles from either clone 3087 or clone 3088.

B. The concentration of chlorophyll B was greater in needles sampled in March 1990 than those sampled in November 1989. The concentration in needles 
Table 2. Summary of foliar nutrient concentration ANOVA. Significant sources of variation are denoted by ${ }^{* *}(\alpha<0.001)$, ** $(\alpha<0.01)$, or $*(\alpha<0.05)$. Nonsignificant sources of variation are indicated by ns. $\mathrm{M}=$ Month; $\mathrm{C}=$ Cione; $\mathrm{O}=\mathrm{Ozone} ; \mathrm{M} \times \mathrm{C}=$ Month $\times$ Clone interaction; $\mathrm{MxO}=$ Month $\times$ Ozone interaction; $\mathrm{CxO}=$ Clone $\times$ Ozone interaction; and $\mathrm{MxC} \times \mathrm{O}=$ Month $\times$ Clone $\times$ Ozone interaction.

\begin{tabular}{|c|c|c|c|c|c|c|c|}
\hline \multirow[b]{2}{*}{ Element } & \multicolumn{7}{|c|}{ Significance level } \\
\hline & $\overline{\mathrm{M}}$ & C & $\mathrm{O}$ & $\mathrm{M} \times \mathrm{C}$ & $\mathrm{M} \times \mathrm{O}$ & $\mathrm{CxO}$ & $\mathrm{M} \times \mathrm{C} \times \mathrm{O}$ \\
\hline Nitrogen & $* * *$ & $* * *$ & ns & ns & ns & ns & ns \\
\hline Phosphorus & $* * *$ & $* * *$ & ns & ns & ns & ns & ns \\
\hline Calcium & $* *$ & $* * *$ & ns & ns & ns & ns & ns \\
\hline Màgnesium & ns & $* * *$ & ns & ns & ns & ns & ns \\
\hline Potassium & ns & $* * *$ & ns & is & ns & ns & ns \\
\hline Sodium & ns & ns & * & ns & ns & ns & ns \\
\hline Marnganese & ns & $* *$ & ns & ns & ns & ns & ns \\
\hline Alıminum & ns & ns & ** & ns & $n s$ & ns & ns \\
\hline Iron & ns & ns & ns & ns & ns & ns & ns \\
\hline $\operatorname{Znc}$ & $* *$ & $* n *$ & ns & ns & ns & ns & ns \\
\hline Sulfur & ns & $* *$ & ns & ns & ns & ns & ns \\
\hline Copper & ns & * & ns & ns & ns & ns & ns \\
\hline Bisron & $* * *$ & $* 4 *$ & ns & ns & $n s$ & ns & ns \\
\hline
\end{tabular}

Table 3. Summary of pigment concentration ANOVA. Significant sources of variation are denoted by ${ }^{* * *}(\alpha<0.001),{ }^{* *}(\alpha<0.01)$, or $*(\alpha<0.05)$. Non-significant sources of variation are indicated by ns. $\mathrm{M}=$ Month; $\mathrm{C}=$ Clone; $\mathrm{O}=\mathrm{Ozone}$; $\mathrm{M} \times \mathrm{C}=$ Month $\times$ Clone interaction; $\mathrm{MxO}=$ Month $\times$ Ozone interaction; $\mathrm{CxO}=$ Clone $\mathrm{x}$ Ozone interaction; and $\mathrm{M} \times \mathrm{C} \times \mathrm{O}=$ Month $\times$ Clone $\times$ Ozone interaction.

\begin{tabular}{llllllll} 
& \multicolumn{7}{c}{ Significance level } \\
\cline { 2 - 7 } & Parameter & $\mathrm{M}$ & $\mathrm{O}$ & $\mathrm{M} \times \mathrm{C}$ & $\mathrm{M} \times \mathrm{O}$ & $\mathrm{C} \times \mathrm{O}$ & $\mathrm{M} \times \mathrm{C} \times \mathrm{O}$ \\
\hline Chlorophyll A & ns & $* * *$ & $\mathrm{~ns}$ & $\mathrm{~ns}$ & $\mathrm{~ns}$ & $\mathrm{~ns}$ & $\mathrm{~ns}$ \\
Chlorophyll B & $* * *$ & $* *$ & $\mathrm{~ns}$ & $\mathrm{~ns}$ & $\mathrm{~ns}$ & $\mathrm{~ns}$ & $\mathrm{~ns}$ \\
Carotenoids & $* * *$ & $* * *$ & $\mathrm{~ns}$ & $* *$ & $\mathrm{~ns}$ & $\mathrm{~ns}$ & $\mathrm{~ns}$ \\
Chlorophyil A/B & $* * *$ & $* * *$ & $\mathrm{~ns}$ & $* *$ & $\mathrm{~ns}$ & $\mathrm{~ns}$ & $\mathrm{~ns}$ \\
\hline
\end{tabular}


taken from clone 3399 was greater than the concentration in needles taken from either clone 3087 or clone 3088.

C. The concentration of carotenoid pigments was greater in needles from clone 3399 taken in November 1989 than those taken in March 1990. There were no significant differences in carotenoid concentrations between clones 3087 and 3088 in either November or March.

D. The chlorophyll A/B ratios in needles sampled in November 1989 were greater than those needles sampled in March 1990. In November, the ratio for needles from clone 3399 was significantly greater than that of clone 3087 . There were no significant differences in the ratios among clones in March.

\subsubsection{Antioxidants}

Antioxidant enzymes (superoxide dismutase and peroxidases) and a metabolite (glutathione) are being examined in the mature needle tissue of clone 3399 of Ponderosa pine. The six trees of clone 3399 or a total of 24 branches are under consideration. We included all treatment combinations of ozone $\left(\mathrm{O}_{3}\right)$, acid precipitation (AP), and nonchambered control branches. This resulted in 12 treatment combinations and 2 replicate branches per combination.

\subsubsection{Methods Development}

Methods for the extraction and assay of the antioxidant enzymes and glutathione were obtained from the literature and modified. The procedures include the following:

a. Superoxide dismutase (SOD) and peroxidase extraction.

b. Glutathione extraction.

c. SOD assay including

OD560 versus reaction time.

$\mathrm{OD}_{560}$ versus volume of enzyme extract.

d. Guaiacol-oxidizing peroxidase assay.

e. Ascurbate peroxidase assay.

f. Glutathione assay.

g. Bradford assay (protein).

We have established and optimized methods for the two extractions and for three enzyme assays. SOD and peroxidase procedures are described in Appendix B along with references. An ophthaldehyde (OPT) derivitization and fluorescence detection method was investigated for the assay of glutathione; however, poor recovery and detection of internal standards of commercial glutathione (oxidized and reduced forms) has led us to begin work on the dithionitrobenzoic acid (DTNB) reduction method. Sampling and extraction for glutathione will be conducted this summer. The glutathione extracts will be frozen and stored at $-70^{\circ} \mathrm{C}$ and the assays will be run in the fall. We are currently sampling, extracting, and conducting the assays for SOD and the peroxidases. 


\subsubsection{Within-Branch Variability Sampling and Assays}

In February, 12 fascicles of current-year needles were harvested from a nonexperimental branch of clone 3399 to establish baseline antioxidant activities and background variation. Mean SOD activity was $138.5 \pm 15$ (SD) units mg- $^{-1}$ protein, and mean activity of guaiacol-oxidizing peroxidases was $89 \pm 19$ (SD) $\triangle \mathrm{A}_{470} \mathrm{~min}^{-1} \mathrm{mg}^{-1}$ protein.

\subsubsection{Diurnal Variability Sampling and Assays}

A five-point diurnal needle sampling was conducted to determine possible diurnal patterns in the activity of antioxidant enzymes, perhaps in response to light, temperature, and ambient ozone. If diurnal trends were present, we would use this information to choose the appropriate time of day for needle sampling for seasonal and episodic investigations.

We sampled clones 3399 and 3088 to determine diurnal variability. We found no significant diurnal trends in the activity of antioxidant enzymes. On the day we sampled, it was breezy, temperatures were mild (ranging from $14^{\circ}$ to $33^{\circ} \mathrm{C}$ ), and ozone concentrations were low (ranging from $0.015 \mathrm{ppm}$ to $0.033 \mathrm{ppm}$ ). Because there were minimal variations in temperature and ozone, there may not have been any significant environmental influence that would result in possible diurnal variations in antioxidant enzyme activity. We hope to conduct another diurnal sampling later in the summer, on a day in which there are greater fluctuations in temperature and ambient ozone.

\subsubsection{Seasonal Variability Sampling and Assays}

Wo have completed two points of a five-point seasonal sampling for antioxidant enzymes. These were conducted the first week of May and June, and they were accompanied by diurnal physiological measurements (photosynthesis, respiration, and stomatal conductance) using the Licor 6200 . We are currently analyzing the physiological data, and extraction of the harvested needles has begun. The seasonal physiological and antioxidant measurements will be taken in the first week of July.

\subsubsection{Episode Variability Sampling and Assays}

Episodic sampling is dependent upon the occurrence of a several-day period of elevated ambient ozone. Dr. John Carroll, an air-pollution meteorologist at UC Davis, has described the conditions when ozone episodes would occur in the Chico area. Relatively clean air is expected when $10-15 \mathrm{mph}$ winds from the north and northwest are present; however, as these winds stagnate and the air is relatively calm, ozone concentrations tend to increase. If the weaker winds from the south of Chico (Sacramento) and the coastal breezes increase, ozone levels will increase because of the transport of pollutant precursors from Sacramento, Stockton, and perhaps the Bay Area. Pollutant concentrations should decline upon the return of 
north and northwest winds. Temperature is also a factor, with higher ozone concentrations expected during periods of high temperatures. If the weather conditions are appropriate, episode sampling for antioxidants will be conducted in August or September.

\subsubsection{Interpretation of Preliminary Data}

The diurnal antioxidant data showed a high level of variability in the enzyme activity. We are concerned about whether antioxidant response to air pollutants might be small compared to background variation (due to environmental variables and extraction and assay procedures), which may be significant. Therefore, we are addressing and attempting to reduce the variability detected in this preliminary data.

Enzyme activities expressed on a per-ml-extract basis showed lower variability than did activities expressed on a per-mg-extracted-protein basis, the latter being the standard way to express enzyme activities for tissue extracts. This trend was especially true for ascorbate peroxidase activity. We examined the Lowry Assay as an alternative to the Bradford method of protein determination. We found close agreement and similar variability in protein determination by both the Bradford and Lowry methods. Therefore, it is likely that the variability in the enzyme data arises from the extraction procedure and not from the method of protein determination.

We are currently examining the extraction procedure reported in Appendix $B$. The following two modifications are under consideration:

A. Needles may first be ground in liquid nitrogen before homogenization in the polytron. The objective is to achieve a uniform and complete dissolution of the tissue. The extracts have only a very slight green color indicating that many of the chloroplasts remain intact and are precipitated during centrifugation and that most of the proteins released are cytoplasmic. The additional grinding step, and perhaps sonication of the extract before centrifugation, could ensure a more uniform release of proteins, including chloroplast proteins.

B. Insoluble polyvinylpolypyrrolidone (PVPP) may be added during tissue homogenization to precipitate polyphenols. Ideally, PVPP should be added during the homogenization to remove phenolics from the solution immediately; however, the homogenization can dissolve a small amount of the PVPP. Addition of the PVPP after homogenization, or an ether separation of the extract after centrifugation, would eliminate the problem. The ether would also remove Triton $X-100$, the detergent used in the extraction medium. We found that Triton $X-100$ can cause interference in the protein assay but that the dialysis step removes most of the detergent. The ether separation could improve the removal of both of these compounds. Both PVPP and Triton $X-100$ are required for the extraction procedure, but the $;$ have the potential to interfere with the enzyme assays or the protein determination. 


\subsection{Branch Autonomy}

\subsubsection{Introduction}

We need to validate the use of branch chambers, and branches as surrogates for whole trees for our research, as well as to prepare for future research. We can address this concern by examining some recent research. Teskey and Dougherty (personal communication, 1990) conducted a pulse-chase ${ }^{14} \mathrm{C}$ experiment on stressed branches by using various levels of shade to reduce branch carbon uptake and, therefore, growth (similar to a branch receiving ozone). They pulsed a neighboring branch with ${ }^{14} \mathrm{C}$ to determine if the shaded branch (which is now a potential sink) was receiving carbon from its neighboring branch. They monitored the movement of ${ }^{14} \mathrm{C}$ over a period of time and found no detectable levels of ${ }^{14} \mathrm{C}$ in the shaded branch. Hypothetically, this branch study could be related to a potential study involving ozone, where a branch accumulating less carbon (similar to the shaded branch) than a neighboring branch (similar to the unshaded branch) would not import needed carbon from a potential source-its neighboring branch (similar to the unshaded branch).

We have elected to address this concern by testing for the degree of carbon autonomy within branches of Pinus ponderosa. Detailed methods are given in Houpis and Cowles (1989). In our branch autonomy study, we wanted to determine if the location of a branch in the canopy (top or south facing) or branch dominance (apical or lawial branch) would influence the amount of carbon exported from a branch and imported into neighboring branrhes. In all cases, we pulsed a branch (whether an apical or lateral) with ${ }^{14} \mathrm{CO}_{2}$ and monitored the flow of ${ }^{14} \mathrm{C}$ through three subtending whorls of branches. In the following section, we report on the results for a November pulse (when carbon should be movirig toward storage) oi apical and lateral branches, and from the top of the canopy.

\subsubsection{Results}

Figure 2 shows that 83.4 percent of the ${ }^{14} \mathrm{C}$ detected after 8 days of translocation remained in the apical branch (A1), which was initially pulsed with ${ }^{14} \mathrm{CO}_{2}$. Of this 83.4 percent, 60.7 percent was found in the needles, 20.9 percent in the stems, and 1.8 percent in the buds. After the A1 sampling position, the greatest accumulation of carbon external to the pulsed rranch occurred in the S1 and S4 sampling positions with 9.8 percent and 5.9 percent, respectively. It should be noted that along the main stem, the farther the sampling point was from the pulsed point, the lower the percentage of ${ }^{14} \mathrm{C}(\mathrm{S} 1>\mathrm{S4})$. The results also show that there was no significant movement of carbon toward any of the subtending branches. After 8 days, there was a total of 0.9 percent of ${ }^{14} \mathrm{C}$ that was located in any of the subtending whorls (excluding S1 and S4). Furthermore, only 0.9 percent was found in all nonpulsed needle tissue. This is particularly important, considering ozone will initially damage needle tissue. 


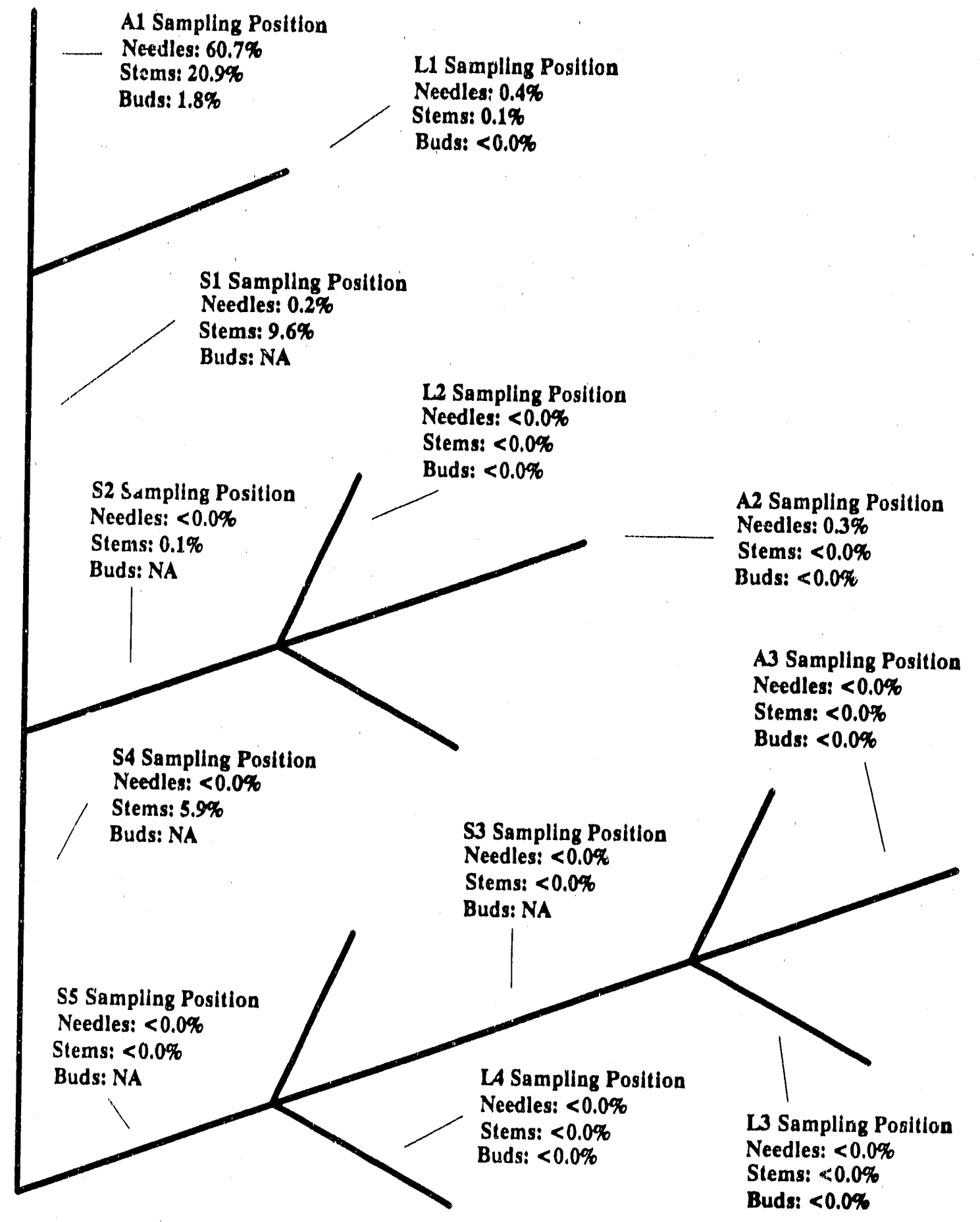

Figure 2. Translocation from an A1-pulse position. Percent of total ${ }^{14} \mathrm{C}$ remaining after 8 days of translocation following an apical pulse, for each tissue type in each sampling position. 
The results for the lateral branches, which were pulsed with ${ }^{14} \mathrm{CO}_{2}$, are very similar to those where an apical branch was pulsed (Fig. 3). There are two notable results (Fig. 4). First, carbon only moves down the main stem. This can be observed by noting that only 0.1 percent of the ${ }^{14} \mathrm{C}$ found after eight days of translocation had moved into the A1 position. Second, L1 nonpulsed branches (which are adjacent to the pulsed branch) received only 0.1 percent of the translocated carbon. Again, most of the translocated carbon was found in the S1 and S4 positions with 6.7 percent and 5.7 percent, resprctively.

\subsubsection{Discussion}

The results show that most of the ${ }^{14} \mathrm{C}$ remaining after 8 days of translocation was still in the labelled branch, and very little carbon ( 0.5 percent) was found in nonlabelled needle tissue and nonmain stem tissue ( 0.1 percent). The major amount of export ( 15.5 percent) rvent to the stem segments immediately below the pulsed stem. (The pulsed stem's contribution to other stem's carbon accumulation decreased with distance from the pulsed stem.) This study, as well as others, has demonstrated that branches contribute to carbon needs for themselves and secondly to the immediate vicinity of where they are growing; i.e., branches located near the base of the tree contribute more toward root growth than branches near the top of the crown.

\subsection{Quality Assurance}

Several quality assurance monitoring procedures have been implernented during the last quarter. All laboratory analyses now include an active quality assurance audit program. Duplicate samples are being included with experimental samples at a rate of 15 percent for chlorophyll and antioxidants. Duplicate samples are being analyzed at a rate of 12 percent for foliar nutrients. In addition, standard and blind audit foliage samples received from the Environmental Protection Agency (EPA) in Corvallis have been included for nutrient analyses with the samples collected in March.

There are few quality assurance results to report. Presently, the amount of data is insufficient to develop quality control charts; only two points per parameter could be plotted.

Instrument performance analyses are also underway. The ozone-transfer standard used for ozone-analyzer calibration was rechecked and recertified by the California Air Resources Board in February. Zoro-span checks of all ozone analyzers are currently being made biweekly. As time permits, zero-span check frequency will be increased to a weekly basis.

Responding to a quality assurance/quality control request by Steve Cline of the EPA, we have developed and provided the standard operating procedure for antioxidant methods (Appendix B). 


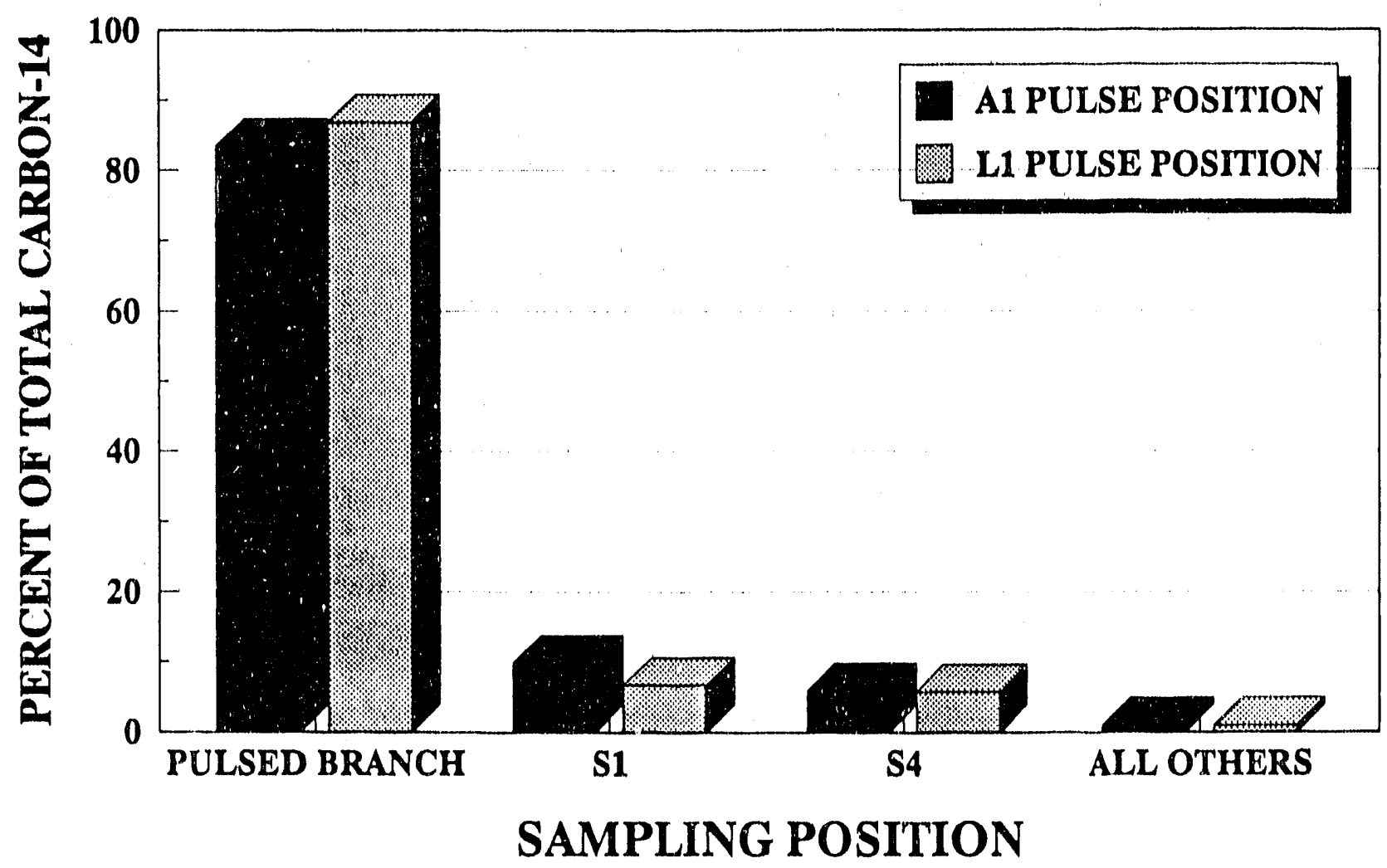

Figure 3. A comparison of an apical pulse and a lateral pulse. 


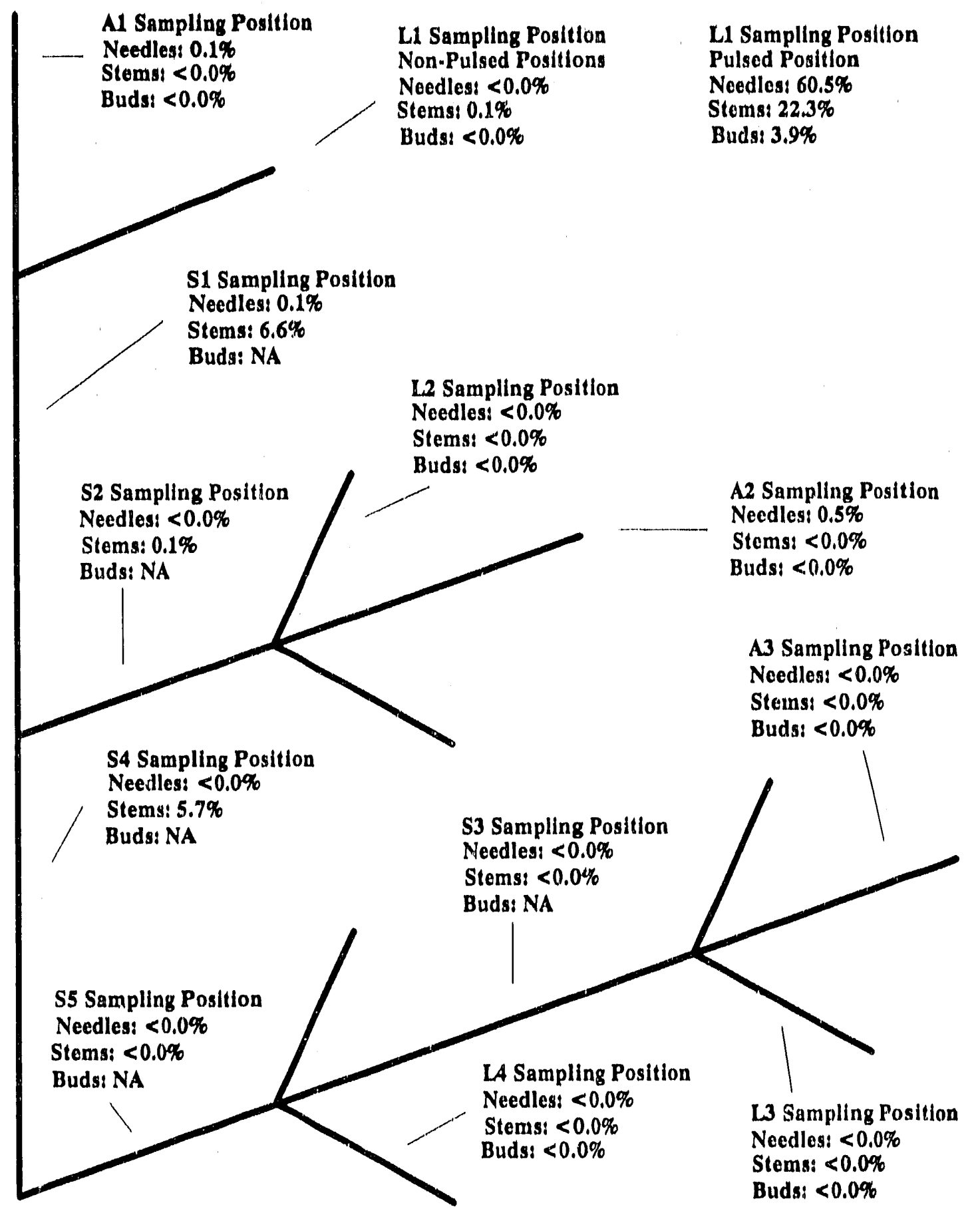

Figure 4. Translocation from a $\mathrm{L} 1$ pulse position. Percent of total ${ }^{14} \mathrm{C}$ remaining after 8 days of translocation following a lateral pulse, for each tissue type in each sampling position. 


\subsection{SUMMARY}

We have resolved most of the electrical and mechancal problems that had resulted in interrupted exposures. Currently, the operation of the Chico Air Pollution and Climate Change Research Facility is routine. This has allowed us to concentrate on data collection.

Over the last eight months, a substantial database has been accumulated. This database consists of environmental, physiological, morphological, and growth measurements. To date, these data indicate that there has not been any effect due to ozone or acid rain. This was to be expected because the seedlings and branches have not experienced any extended periods of ozone exposure. However, in the coming months (July to October 1990) ambient concentrations should increase substantially, We would expect that if there is a response of Pinus ponderosa to ozone exposures, it may be detectable in the July measurement period (possibly with pigmentation and antioxidant measurements), but, more likely, it will be detectable during the October measurement period (possibly with pigmentation, antioxidant, nutrient analysis, and gas-exchange measurements). Finally, we have analyzed a significant portion of the branch autonomy study, and we are confident that the branches of Pinus ponderosa are autonomous units.

In the coming months, we will continue ozone and acid-precipitation exposures. We will also conduct major physiological measurements in the month of July; continue growth, morphological, and water relation measurements; and complete the analysis of the November branch autonomy study. These items will be reported in the October 1990 Annual Report.

\subsection{REFERENCES}

Houpis, J.L.J., and S. Cowles, 1989. Annual Report for the Project "Comparison of the Response of Mature Branches and Seedlings of Pinus ponderosa to Atmospheric Pollution." Reported to: U.S. Environmental Protection Agency. University of California, Lawrence Livermore National Laboratory, Livermore, CA. UCRL-2116989. $64 \mathrm{pp}$.

Houpis, J.L.J., K.A. Surano, and S. Cowles. 1987. Work Plan for the Project "Comparison of the Response of Mature Branches and Seedlings of Pinus ponderosa to Atmospheric Pollution." Reported to the following Agencies: Environmental Protection Agency, Western Conifer Research Cooperative, and the National Council for Air and Stream Improvement. University of California, Lawrence Livermore National Laboratory, Livermore, CA. UCRL-21001-88-4. 80pp. 


\subsection{APPENDICES}

\section{Appendix A: External Project Reporting}

\section{Presentations:}

Anderson, P.D. 1990. The establishment of a facility for the long-term exposure of mature branches and seedlings of ponderosa pine (Pinus ponderosa) to ozone and acid rain. Proceedings of the 13 th North American Forest Blology Workshop. Athens, Georgia.

Houpis, J.L.J. 1990. Innovative methods for comparing the physiolu fical and morphological response of seedlings and mature trees to air pollution. California State University, at Chico.

Houpis, J.L.J., P.D. Anderson, M.P. Costella, 1990. An in-depth comparison of the physiology and morphology of mature branches and seedlings at the Chico Air Pollution and Climate Change Research Facility. 21st Annual Air Pollution Workshop. Toronto, Ontario, Canada.

\section{Publications (Submitted and In Print)}

Anderson, P.D., J.L.J. Houpis, L.E. Neuman, S.P. Phelps, A.T, Loefler, S.E. Benes. 1990. The establishment of a facility for the long-term exposure of mature hranches and seedlings of ponderosa pine (Pinus ponderosa) to ozone and acid rain. In: Proceedings of the 13th North Arnerican Forest Blology Workshop. Athens, Georgia.

Benes, S.E., T.M. Murphy, P.D. Anderson, J.L.J. Houpis, A. Lauchli. 1990. Antioxidant activity in mature branches of ponderosa pine (Pinus ponderosa) under long-term, low concentration ozone exposure. Supplement to: Plant Physiology 93:100.

Houpis, J.L.J., M.P. Costella, and S. Cowles. 1990. A branch exposure chamber for fumigating mature branches of Pinus ponderosa to atmospheric pollution. J. Environ. Quality (submitted).

Houpis, J.L.J., M.P. Costella, and S. Cowles, 1990. Gas-exchange Measurements of a mature branch using a branch exposure chamber. Tree Physiol. (submitted). 
Houpls, J.L.J., J.A. Helms, M.P. Costella, 1990. Scasonal needle chlorophyll and carotenold content of Pinus ponderosa seedlings subjected to long-term sulfur dioxide and water stress. Plant Physiol. (submitted).

Neuman, L., J.L.J. Houpis, P.D. Anderson. 1990. Among-clone comparison of the response of photosynthetic pigments in mature branches of Pirus ponderosa to longterm exposure of ozone and acid rain. Supplement to: Plant Physiology 93:101.

Phelps, S.P., J.L.J. Houpis, P.D. Anderson, 1990. Comparison of stomatal conductance among clones of Pinus ponderosa exposed to varying levels of ozone. Supplement to: Plant Physiology 93:160. 
Appendix B: Standard Operating Procedure for Antioxidant Analyses

Section 2

Revision 2

Date: 16 April 1990

\section{Scope and Purpose}

Superoxide dismutase (SOD) and peroxidases are antioxidant enzymes that, respectively, remove the free radical superoxide $\left(\mathrm{O}_{2}^{-}\right)$and hydrogen peroxide $\left(\mathrm{H}_{2} \mathrm{O}_{2}\right)$ from the cell. The $\mathrm{O}_{2}{ }^{-}$and $\mathrm{H}_{2} \mathrm{O}_{2}$ can be produced in plant cells exposed to oxidant stress such as ozone. The following SOP is used for SOD and peroxidase extraction and assay using Pinus ponderosa needle tissue.

\section{Materials and Supplies}

\subsection{Equipment}

a. Liquid nitrogen (LN) dewars-5-1 dewar for field transport of LN and 0.75-1 LN cylinder for needle freezing. Aluminum basket for removing needles from cylinder of $\mathrm{LN}$.

b. Plastic sample bags

c. Ice chest with dry ice

d. $-70^{\circ} \mathrm{C}$ freezer

e. Polytron tissue homogenizer

f. Laboratory centrifuge capable of $20,000 \mathrm{~g}$ rotation

g. Visible light spectrophotometer

h. 8-x-50-ml plastic centrifuge tubes

i. Dialysis tubing (12-14,000 MW cutoff)

j. $0-200 \mu \mathrm{l}$ and $200-1000 \mu \mathrm{l}$ automatic pipette

k. 34-x-22-x-4-cm rectangular glass Pyrex pan

1. Thermometer

$\mathrm{m}$. Lauda constant temperature, circulating and cooling water bath

\subsection{Reagents/Solutions}
a. SOD and peroxidase extraction medium: $50 \mathrm{mM} \mathrm{KPO}_{4}$ buffer ( $\mathrm{pH} 7.8$ ), $0.1 \mathrm{mM}$ EDTA, $0.5 \%(\mathrm{w} / \mathrm{v})$ Triton $X-100$. Prepare $2 x$ concentrated.
b. Insoluble polyvinylpolypyrrolidone (PVPP)
c. Dialysis buffer: $2 \mathrm{~L} 50 \mathrm{mM} \mathrm{KPO}_{4}$ buffer (pH 7.8)
d. SOD reaction medium: $50 \mathrm{mM} \mathrm{KPO} 4$ buffer (PH 7.8), EDTA $0.1 \mathrm{mM}$, $13 \mathrm{mM}$ methionine.
e. Nitrobluetetrazolium (NBT) $7.5 \mathrm{mM}$
f. Riboflavin $0.2 \mathrm{mM}$
g. Commercial bovine erythrocyte SOD $(0.1 \mathrm{mg} / \mathrm{ml})$
h. Commercial bovine serum albumin (BSA), $(0.3 \mathrm{mg} / \mathrm{ml})$ 
1. Guaiacol peroxidase reaction medium: $150 \mathrm{mM} \mathrm{PO}_{4}$ buffer ( $\mathrm{pH}$ 6.1) and $48 \mathrm{mM}$ guaiacol

j. Hydrogen peroxide $\left(\mathrm{H}_{2} \mathrm{O}_{2}\right) 6 \mathrm{mM}$

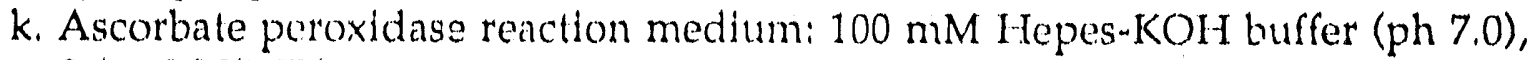
$0.1 \mathrm{mM}$ EDTA.

1. Sodium ascorbate $300 \mu \mathrm{M}$

m. $\mathrm{H}_{2} \mathrm{O}_{2} 300 \mu \mathrm{M}$

\section{Procedure}

\subsection{Sample Preparation}

\subsubsection{Needle Harvest}

Needles are harvested at an hour of the day corresponding to high antioxidant activity. This is determined by diurnal sampling and analysis of diurnal fluctuation in SOD and peroxidase activity. This sampling and analysis is currently underway. It is likely that enzyme activity will follow or lag slightly behind the daily fluctuation in ambient ozone concentration.

A sample consists of one fascicle which, in mature branches of Ponderosa pine, should yield approximately one gram fresh weight of needle tissue. This sample size is sufficient for extraction and assay of all three antioxidant enzymes.

The fascicle is pulled from the stem segment enclosed within the branch exposure chamber (BEC) and is immediately frozen in liquid nitrogen contained in the 0.75 liter dewar. Needles are retrieved from the liquid nitrogen by using the aluminum basket. The needles are placed in a pre-labelled sample bag and placed in an ice chest containing dry ice. The samples are transported on dry ice to UC Davis and placed in a $-70^{\circ} \mathrm{C}$ freezer until extraction. Enzyme extraction is conducted within 2-3 weeks of needle harvest.

\subsubsection{Enzyme Extraction}

One gram of needle tissue, (approximately) one fascicle, is cut into $0.3-\mathrm{cm}$ segments and placed in a $50-\mathrm{ml}$ plastic centrifuge tube containing $6 \mathrm{ml}$ of cold extraction medium and $0.3 \mathrm{~g}$ of insoluble PVPP $[=5 \%(\mathrm{w} / \mathrm{v})$ PVPP]. The centrifuge tube is placed in ice in an ice bucket, and the tube and bucket are elevated for grinding. The tissue is ground with a chilled polytron blade using $2 \times 15 \mathrm{sec}$ lowrspeed pulses and cleaning the blades between pulses. Immediately after grinding, the centrifuge tube is placed in ice in a separate ice bucket to await the completion of 8 samples before centrifugation.

Homogenates are spun at $20,000 \mathrm{~g}$ for $20 \mathrm{~min}$. The supernatant is collected, and the volume is recorded. The supernatant is then dialyzed overnight in the dark against 21 of dialysis buffer, which is changed twice during the period of approximately 12-16 h. Following dialysis, the enzyme extracts are stored in plastic vials at $-70^{\circ} \mathrm{C}$ until assay. In the literature it has been reported that extracts can be stored at $-20^{\circ} \mathrm{C}$ for 30 weeks without losing significant activity (Polle 1989). We have placed a 3 month storage limit on our samples stored at $-70^{\circ} \mathrm{C}$.

\subsection{Measurement Execution/Equipment Operation}

\subsubsection{SOD Assay}

All enzyme extracts (samples) are assayed in a single SOD assay. Two tubes (20 and $40 \mu \mathrm{l}$ extract) are run for each sample. A blank consisting of reaction mix 
and NBT is used to zero the spectrophotometer. A control tube (minus enzyme extract) is run at the beginning and between every four samples. Control tubes are ruin at a high frequency because SOD activity is expressed in terms of the percent inthibition of control absorbance (i.e., the inhibition of NBT reduction and blue formazan formation). To each test tube is added $1 \mathrm{ml}$ of reaction medium, 20 or 40 $\mu \mathrm{l}$ 'enzyme extract $(0 \mu \mathrm{l}$ for control tubes), $20 \mu \mathrm{l}$ NBT solution, and $20 \mu \mathrm{l}$ riboflavin solution (to be added last). Distilled, deionized water is added to give a final reaction volume of $2 \mathrm{ml}$. The tubes are placed in a test tube rack in a glass pyrex pan filled with water maintained at $25^{\circ} \mathrm{C}$. The pan is placed above a set of high-intensity fluorescent lights, and the tubes are illuminated for $8 \mathrm{~min}$ for temperature equilibration. At 1-min intervals riboflavin is added to successive tubes, and the reaction is run with continued illumination for $12 \mathrm{~min}$. At the end of the reaction period each test tube is removed from the lights and absorbance is read at $560 \mathrm{~nm}$.

For each measurement, the spectrophotometer is zeroed with a cuvette containing nonilluminated reaction mix minus riboflavin addition. At the start of the assay; blank and sample cuvettes are checked for absorption differences.

Protein determination for each enzyme extract is determined via the method of Bradford. SOD activity is expressed as 1 unit $=50 \%$ inhibition of NBT reduction of control tubes. Activity is expressed as SOD units $\mathrm{mg}^{-1}$ protein.

\subsubsection{Peroxidase Assay}

The enzyme extract described is used for SOD and peroxidase assays. Peroxidase activity is assayed utilizing two substrates, guaiacol and ascorbate. The objective is to investigate a large general pool of peroxidases, which use guaiacol as a substrate as well as a smaller pool of ascorbate peroxidases, which use ascorbate and which the literature suggests to be more responsive to ozone (Peters et al., 1988).

\subsubsection{Guaiacol Peroxidase}

The reaction mix is as follows:

$1 \mathrm{ml} \mathrm{H} \mathrm{O}_{2}$ (6 mM).

$1 \mathrm{ml}$ guaiacol peroxidase reaction medium.

$1 \mathrm{ml}$ distilled deionized water.

The spectrophotometer is set to a measurement wavelength of $470 \mathrm{~nm}$ with a cuvette containing the $3 \mathrm{ml}$ of reaction mix. The strip chart recorder trace is set with a baseline of 0.000 absorbance (left margin of chart paper) and a right margin of 0.4000 absorbance. The strip chart recorder is set to a $10-\mathrm{mV}$ sensitivity and a chart speed of $4 \mathrm{~cm} \mathrm{~min}^{-1}$.

The reaction mix is prepared in a 3-ml cuvette. Twenty $\mu \mathrm{l}$ of enzyme extract is added to the cuvette, which is inverted quickly to mix enzyme and reaction mix and is immediately placed in the spectrophotometer. The strip-chart recorder is turned on, and activity is measured until a linear trace is obtained. If a linear trace cannot be obtained the enzyme extract should be diluted or the volume of the aliquot can be reduced to $10 \mu \mathrm{l}$.

Guaiacol-oxidizing peroxidase activity is calculated as $\Delta \mathrm{A}_{470} \mathrm{~min}^{-1} \mathrm{mg}^{-1}$ protein (see calculations). Protein concentration of the enzyme extract is as described for the SOD assay, determined by the method of Bradford. 


\subsubsection{Ascorbate Peroxidase}

The reaction mix is as follo, vs:

$1 \mathrm{ml} \mathrm{H} \mathrm{O}_{2}(300 \mu \mathrm{M})$

$1 \mathrm{ml}$ ascorbate peroxidase reaction medium

$1 \mathrm{ml}$ ascorbate $(300 \mu \mathrm{M})$

The spectrophotometer is set to a measurement wavelength of $265 \mathrm{rmm}$ and zeroed with a reagent blank of $1 \mathrm{~m} !$ each of $\mathrm{H}_{2} \mathrm{O}_{2}$, ascorbate reaction mix, and water. The strip chart recorder is set as described in section 3.2.2.1 with the exception that the absorbance range across the chart paper is 0.000 to 0.100 and the chart speed is $2 \mathrm{~cm} / \mathrm{min}$.

The reaction mix is prepared in a $3-\mathrm{ml}$ plastic cuvette. Twenty $\mu \mathrm{l}$ of undiluted enzyme extract is added to the cuvette, which is inverted and quickly placed into the spectrophotometer. The presence of ascorbate in the reaction mix results in a large increase in light absorption. The recorder pen is brought back on scale using the zero knob for the spectrophotometer unit.

Note: The zero knob for the strip chart recorder should not be touched since the right and left margins for the chart paper have already been set.

Once the pen has been brought back on scale a slow decrease in $\mathrm{A}_{265}$ is recorded as the ascorbate is oxidized to dehydroascorbate.

Ascorbate peroxidase activity is calculated from $\Delta \mathrm{A}_{265} \mathrm{~min}^{-1}$ using the ascorbate extinction coefficient of $13.4 \mathrm{mM} \mathrm{cm}^{-1}$. Activity is expressed as $\mu \mathrm{mol}$ ascorbate oxidized min $^{-1} \mathrm{mg}^{-1}$ protein.

\section{Prevention}

During enzyme extraction, the tissue, solutions, and all equipment must be kept as cold as possible. The extraction should be done as quickly as possible.

\section{Calibration Procedures}

\subsection{Enzyme Recovery During Extraction}

Commercial bovine erythrocyte SOD and horseradish peroxidase will be added in known amounts to calculate percent recovery of ihe enzymes during extraction. During the initial modification of the extraction procedure the commercial enzymes were added to a set of enzyme extracts to check for the presence of inhibitory compounds in the enzyme extracts.

\subsection{Variability in Enzyme Assay Results over Time}

As a means of evaluating variation in enzyme assay procedures, an aliquot of a $0.1-\mathrm{mg} / \mathrm{ml}$ solution of comrnercial SOD or a $1-\mathrm{unit} / \mathrm{ml}$ solution of commercial horseradish peroxidase are run as a sample. From these initial stock solutions, 1-ml aliquots are frozen and stored at $-70^{\circ} \mathrm{C}$. An aliquot of the appropriate enzyme will be run during each assay as a means of evaluating the efficiency and consistency of the assay over time.

\subsection{BSA Standard Curve for Calculation of Extract Protein}

BSA standards are prepared to give a linear range of absorbance at $595 \mathrm{~nm}$. A $0.3 \mathrm{mg} / \mathrm{ml}$ stock solution is used to prepare the standards of $0,5,10,15,20,30$, and $40 \mu \mathrm{g}$ protein. The Bradford assay is used for the protein determination, and extract protein is determined by extrapolation from the BSA standard curve. 


\section{Calculations/Units}

\subsection{SOD Activity}

One unit of SOD activity is defined as the amount of enzyme inhibiting the reduction of NBT by $50 \%$, i.e., sample absorbance equals $0.5 \times$ control absorbance. This definition assumes a linear relationship between $A_{560}$ and the volume of enzyme extract. To better describe the slope of this relationship and to calculate SOD activity, we chose to assay SOD at two different volumes of enzyme extract and to use mathematical equations to obtain an interpolated volume of enzyme extract giving $0.5 \times$ control absorbance.

We determine the two assay volumes by first conducting initial SOD assays across a range of extract volumes and by the results of the protein assays, which determine the protein content of each enzyme extract. With typical assay volumes of 20 and $40 \mu \mathrm{l}$, calculation of SOD activity is as follows:

$$
\begin{aligned}
x_{1} & =0.02 \mathrm{ml} \quad \mathrm{y}_{1}=\mathrm{Abs}_{1} \quad \begin{array}{l}
\text { (experimental values) } \\
\mathrm{x}_{2}
\end{array}=0.04 \mathrm{ml} \quad \mathrm{y}_{2} \text { Abs } \quad \text { (experimental values) } \\
\mathrm{X}_{\mathrm{i}} & =0.5+\left[\left(\mathrm{x}_{1} \mathrm{y}_{2}-\mathrm{x}_{2} \mathrm{y}_{1}\right) /\left(\mathrm{x}_{2}-\mathrm{x}_{1}\right)\right]^{*}\left[\left(\mathrm{x}_{1}-\mathrm{x}_{2}\right) /\left(\mathrm{y}_{1}-\mathrm{y}_{2}\right)\right] \\
& =\text { volume }(\mathrm{ml}) / 1 \text { unit SOD activity (interpolated volum.e) } \\
\mathrm{A} & =1 / \mathrm{X}_{\mathrm{i}}=\text { units } / \text { volume }(\mathrm{ml}) \\
\mathrm{P} & =\mathrm{mg} \text { protein } / \mathrm{ml} \text { (Bradford protein test) }
\end{aligned}
$$$$
\text { SOD Activity }=A / P=\text { units } / \mathrm{mg} \text { protein }
$$

\subsection{Guaiacol Peroxidase Activity}

The oxidation of aiacol by peroxidase is assayed as the increase in light absorption at $470 \mathrm{~nm}(\mathrm{~A}, 0)$ and the reaction is run until a linear trace is obtained on the chart paper. Based on the absorbance range designated across the width of the chart paper $(0.000$ to 0.4000$)$ and the chart speed $(4 \mathrm{~cm} / \mathrm{min})$, the $\Delta \mathrm{A}_{470} \mathrm{~min}^{-1}$ can be calculated.

$$
\begin{aligned}
& \text { Assay volume }=20 \mu \mathrm{l}=0.02 \mathrm{ml}
\end{aligned}
$$

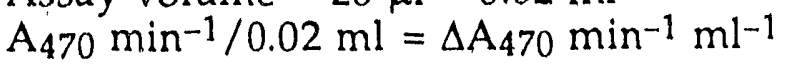

$$
\begin{aligned}
& \text { Guaiacol Peroxidase Activity }=\Delta A_{470} \mathrm{~min}^{-1} \mathrm{ml}_{-1} / \mathrm{mg} \text { protein } \mathrm{ml}^{-1} \\
& =\Delta A_{470} \mathrm{~min}^{-1} \mathrm{mg}^{-1} \text { protein }
\end{aligned}
$$

\subsection{Ascorbate Peroxidase Activity}

The oxidation of ascorbate to dehydroascorbate by ascorbate peroxidase is assayed as the decrease in light absorption at $265 \mathrm{~nm}\left(\mathrm{~A}_{265}\right)$. A linear trace is obtained on the chart paper. Based on the absorbance range designated across the chart paper $(0.000$ to 0.100$)$ and the chart speed $(2 \mathrm{~cm} / \mathrm{min})$, the slope of the trace $\left(\Delta \mathrm{A}_{265} \mathrm{~min}^{-1}\right)$ is calculated: 


$$
\begin{aligned}
& \text { Assay volume }=20 \mu \mathrm{l}=0.2 \mathrm{ml}
\end{aligned}
$$

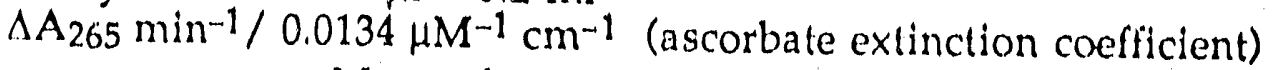

$$
\begin{aligned}
& =\mu \mathrm{M} \text { ascorbate oxidized } \mathrm{min}^{-1} \\
& \mu \mathrm{M} \text { ascorbate } \mathrm{min}^{-1} \times 0.003 \mathrm{~L} \text { (reaction volume) } \\
& =\mu \text { moles ascorbate } \mathrm{min}^{-1} \\
& \text { Hmoles ascorbate } \mathrm{min}^{-1} / 0.02 \mathrm{ml} \text { (enzyme extract aliquot volume) } \\
& =\mu \text { moles ascorbate } \mathrm{min}^{-1} \mathrm{ml}^{-1} \\
& \text { Ascorbate Peroxidase Activity } \\
& =\mu \text { moles ascorbate } \mathrm{min}^{-1} \mathrm{ml}^{-1} / \mathrm{mg} \text { protein } \mathrm{ml}^{-1} \\
& =\mu \text { moles ascorbate } \mathrm{min}^{-1} \mathrm{mg}^{-1} \text { protein }
\end{aligned}
$$

\section{References}

Beauchamp, C., and I. Fridovich. 1974. Superoxide dismutase: improved assays and an assay applicable to acrylamide gel. Anal. Biochem. 44: 276-287.

Beyer, W.F. Jr., and I. Fridovich. 1987. Assaying for superoxide dismutase activity: some large consequences of minor changes in conditions. Anal. Biochem. 161: 559-566.

Castillo, F.J., P.R. Miller, and H. Greppin. 1987. Extracellular biochemical markers of photochemical oxidant air pollution damage to Norway spruce. Experientia 43: 111-115.

Peters, J.L., F.J. Castillo, and R.L. Heath. 1988. Alteration of extracellular enzymes in pinto bean leaves upon exposure to air pollutants, ozone and sulfur dioxide. Plant Physiol. 89:59-164.

Polle, A., B. Krings, and H. Rennenberg. 1989. Superoxide dismutase activity in needles of Norwegian spruce trees (Picea abies L.). Plant Physiol. 90:1310-1315.

Tandy, N. E., R.T. DiGiulio, and C.J. Richardson. 1989. Assay and electrophoresis of superoxide dismutase from red spruce (Picea rubens Sarg.), loblolly pine (Pinus taeda L.), and scotch pine (Pinus sylvestris L.). Plant Physiol. 90: 742-748. 

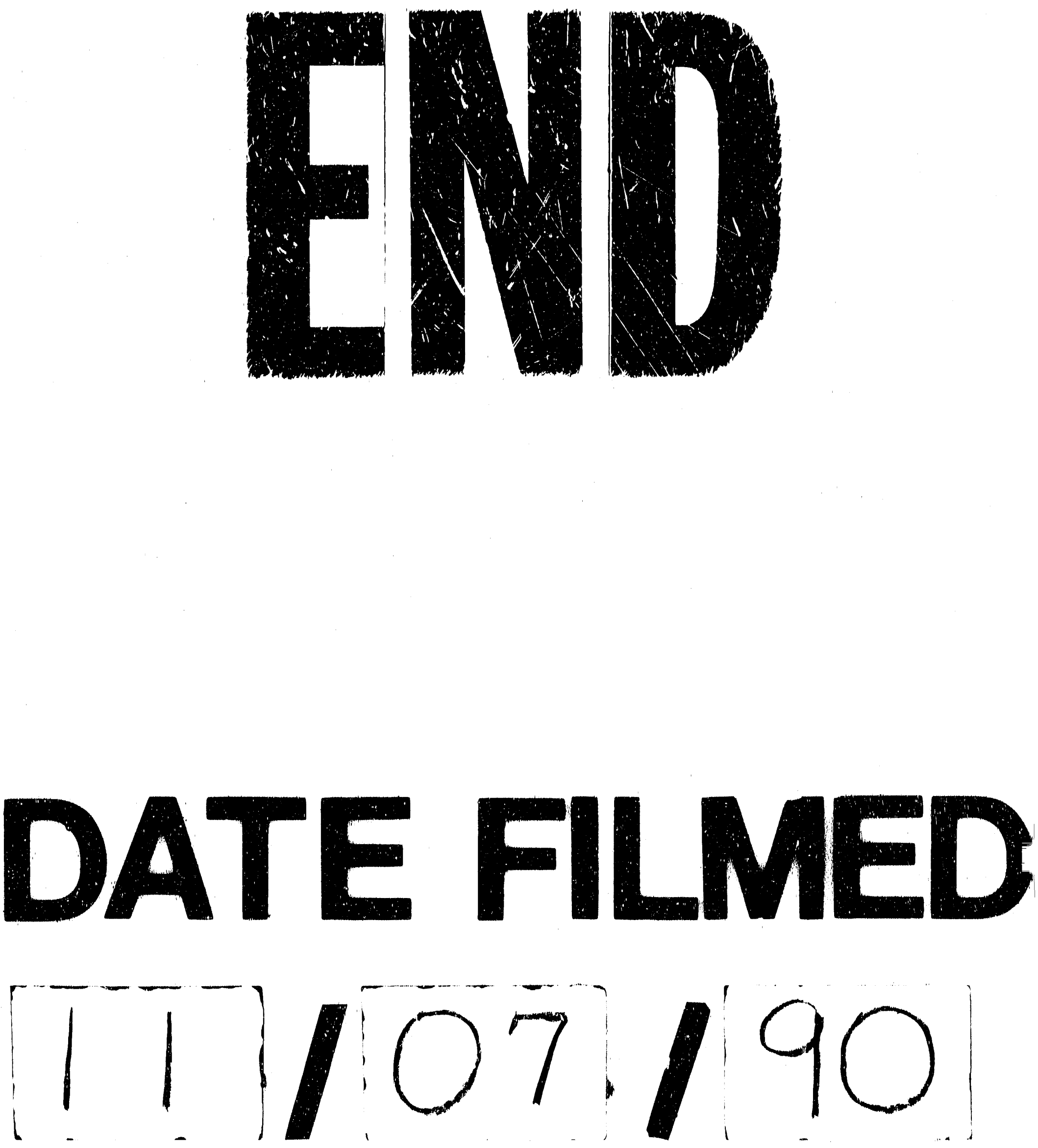
